\title{
Genetic Variation in the Carbonic Anhydrase Isozymes of Macaque Monkeys. IV. Degradation by Heat and Proteolysis of Normal and Variant Carbonic Anhydrase Isozymes of Macaca nemestrina ${ }^{1}$
}

\author{
WILLIAM R. A. OSBORNE ${ }^{2}$ AND RICHARD E. TASHIAN ${ }^{3}$ \\ Department of Human Genetics, University of Michigan Medical School, Ann Arbor, Michigan 48109
}

Received July 29, 1983, and in revised form November 22, 1983

\begin{abstract}
Studies were undertaken on the heat denaturation and proteolytic degradation by $\alpha$-chymotrypsin of the normal red cell carbonic anhydrase isozyme, CA II, and two electrophoretic variants of carbonic anhydrase I, CA Ia and CA Ib, of the pigtail macaque. The heat degradation results showed a difference of about 40 -fold in the rate constants between CA Ia and CA Ib, which is due to the marked thermostability of CA Ib compared to CA Ia. The enthalpies and entropies of activation were calculated from the heat denaturation constants. These values were compared, on enthalpy-entropy compensation plots, with those values previously determined for the human CA I and CA II isozymes. They were highly correlated and clearly fell into two distinct clusters, separated by about $200 \mathrm{~kJ} \mathrm{~mol}^{-1}$; one group comprising the macaque and human CA I isozymes and the other the CA II isozymes. The proteolytic degradation results showed that CA Ia is degraded about 2.5 times more rapidly than CA Ib by $\alpha$-chymotrypsin. Thus, the characteristic $3 / 1$ ratio of $\mathrm{CA} \mathrm{Ib} / \mathrm{CA}$ Ia in mature red cells could be accounted for by the greater susceptibility of CA Ia to degradation at some stage in red cell development.
\end{abstract}

Inherited quantitative deficiencies of proteins range from moderately reduced levels to their virtual absence in cells where they are normally expressed. These deficiencies can result from defects or changes in (a) the rates of synthesis or processing of mRNA transcripts, (b) the translation of mRNA, and (c) the stability of mRNA and/or its protein product. Most of what we know about the molecular bases of inherited protein deficiencies in higher organisms comes from studies of human hemoglobin deficiencies, e.g., the $\alpha$ - and $\beta$ thalassemias (cf. Ref. (1)). With respect to inherited unstable proteins, a considerable

\footnotetext{
${ }^{1}$ Supported by U. S. Public Health Service Grant GM 15419.

${ }^{2}$ Present address: Department of Pediatrics, University of Washington Medical School, Seattle, Wash. 98195.

${ }^{3}$ To whom correspondence should be addressed.
}

amount of information has accumulated concerning the degradation of hemoglobin chains, and the types and location of proteolytic enzymes in human red blood cells (cf. Ref. (2), and refs. therein). Similar information at the molecular level, however, for inherited enzyme deficiencies is more limited (cf. Ref. (3)).

The monomeric carbonic anhydrase (EC 4.2.1.1) isozymes, designated CA I, CA II, and CA III [see (4) for review], appear to be a good model system for the study of inherited enzyme deficiencies. Inherited deficiencies of red cell CA I have been reported in asymptomatic humans (5) and pigtail macaques, Macaca nemestrina (7$9)$. It has also been recently reported that a syndrome of osteopetrosis with renal tubular acidosis is produced in humans who are homozygous for a CA II deficiency gene (6). Those deficiencies which result in the reduction to trace amounts of either CA I 
or CA II in mature red cells are obviously difficult to study at the protein level; however, those mutant carbonic anhydrase isozymes whose levels are not as drastically reduced can be purified and characterized with regard to such parameters as their heat stabilities and proteolytic degradation patterns.

Previous studies in our laboratory on the in vitro translation of two polymorphic ${ }^{4}$ variants of CA I, termed CA Ia and CA Ib, which are differentially expressed in mature red cells of the pigtail macaque, suggested that the reduced levels of CA Ia [which are about one-third those of CA Ib (8)] are due to the greater susceptibility to degradation of CA Ia (8). Since pulse-chase incubation experiments of CA Ia and CA $\mathrm{Ib}$ in reticulocytes indicated that both variants were equally stable, it was hypothesized that the putative degradation takes place earlier in erythroid development (8). The present study was undertaken in order to determine whether a correlation exists between the relative rates of degradation and the characteristic protein levels of CA Ia and CA Ib in mature red cells. This possibility is examined by comparing the rates of proteolysis by $\alpha$ chymotrypsin and denaturation by heat of CA Ia and CA Ib purified from erythrocytes of the pigtail macaque. For comparative purposes with the human carbonic anhydrase isozymes, similar studies were also carried out on the normal red cell CA II isozyme of the pigtail macaque.

\section{MATERIALS AND METHODS}

Reagents. Neoprontosil was obtained from Winthrop Laboratories (New York, N. Y.). All chemicals were reagent grade and supplied by Sigma (St. Louis, Mo.).

Enzymes. $\alpha$-Chymotrypsin was obtained from Worthington Biochemical Corporation (Freehold, N. J.), with an activity of $50.1 \mathrm{units} / \mathrm{mg}$. The carbonic anhydrase isozymes were purified from the erythrocytes of a pigtail macaque that was heterozygous for the $C A I^{\mathrm{a}}$ and $C A I^{\mathrm{b}}$ alleles (7-9). The CA I (CA $\mathrm{Ia}+\mathrm{CA}$ Ib) and CA II isozymes were first separated by affinity chromatography on sulfonamide-bound CM-Sephadex columns by the method of Osborne and

\footnotetext{
- The frequencies of the $C A I^{\mathrm{a}}$ and $C A I^{\mathrm{b}}$ alleles in natural populations of pigtail macaques are 0.38 and 0.57 , respectively (7).
}

Tashian (10). The CA Ia and CA Ib allozymes were then eluted (the more positively charged CA Ia form eluting first) from a DEAE-cellulose (Whatman DE52) column $(1.5 \times 85 \mathrm{~cm})$ with a $0-0.2 \mathrm{M} \mathrm{NaCl}$ gradient containing the column equilibrating buffer $(0.05 \mathrm{M}$ Tris-HCl, $\mathrm{pH} 8.7$ ) at a flow rate of $14 \mathrm{ml} / \mathrm{h}$.

Thermal inactivation. A sulfonamide-binding assay was used to measure heat inactivation rates, as previously described (11). In brief, the enzyme was incubated at the required temperature in $0.01 \mathrm{M} \mathrm{Hepes}^{5}$ $\mathrm{HCl}$ buffer, $\mathrm{pH} 8.4$, at $23^{\circ} \mathrm{C}$. At timed intervals, aliquots were removed and mixed with a standard azosulfonamide solution, which was also used as the reference. The decrease in absorbance given upon azosulfonamide-carbonic anhydrase binding was proportional to the concentration of native enzyme. For the pigtail macaque CA I and CA II isozymes, the maximum absorbance differences were at 505 and $490 \mathrm{~nm}$, respectively.

Proteolytic assay. The rate of proteolysis was measured by incubating $\alpha$-chymotrypsin with the carbonic anhydrase-azosulfonamide complex, as previously described (12). The increase in absorbance given by the release of the bound inhibitor from the active site of carbonic anhydrase was monitored at 505 and $490 \mathrm{~nm}$, respectively, for the CA I and CA II isozymes, using a Beckman recording spectrophotometer with the cell block at $45 \pm 0.1^{\circ} \mathrm{C}$. Duplicate assays were carried out with 10-50 $\mu \mathrm{M}$ carbonic ahydrase, with the corresponding molarity of azosulfonamide plus $10 \%, 17.7 \mu \mathrm{M} \alpha$-chymotrypsin, $83 \mu \mathrm{M} \mathrm{CaCl}_{2}$, and 83 $\mathrm{mm}$ Tris- $\mathrm{HCl}$, pH 8.0 (at $23^{\circ} \mathrm{C}$ ). The absorbance increase was linear for $20-40 \mathrm{~min}$ and was recorded against a reference of buffered azosulfonamide.

At the substrate and enzyme concentrations used, the usual assumption that free substrate equals total substrate is not necessarily valid. The data were therefore analyzed in terms of free substrate (13). The total substrate $\left(S_{\mathrm{t}}\right)$ and the initial velocity $(v)$ were analyzed by the procedure of Wilkinson (14) to give a $V_{\max }$ value, and this was used to calculate free substrate $\left(S_{f}\right)$ by the method of Goldstein (15). These values of $S_{\mathrm{r}}$ with their corresponding initial velocities were then analyzed by the Wilkinson method to give the final $K_{m}$ and $V_{\max }$ values.

Difference spectra. The difference spectra of the azosulfonamide-carbonic anhydrase complexes were recorded using a Zeiss PMQ II spectrophotometer as described previously (11).

\section{RESULTS AND DISCUSSION}

\section{Difference Spectra}

The azosulfonamide difference spectra of the pigtail macaque CA Ib and CA II iso-

\footnotetext{
${ }^{5}$ Abbreviations used: Hepes; 4-(2-hydroxyethyl)-1piperazineethanesulfonic acid.
} 
zymes are shown in Fig. 1, where the negative sign indicates a decrease in absorbance relative to free inhibitor. CA Ia gave essentially the same profile as $\mathrm{CA} \mathrm{Ib}$.

For the CA II isozyme, the wavelength of maximum absorbance difference $\left(\lambda_{\max }\right)$ was at $490 \mathrm{~nm}$ with a molar extinction coefficient $(\Delta E)$ of $10.8 \times 10^{3}$ liters $\mathrm{mol}^{-1} \mathrm{~cm}^{-1}$; and for both $\mathrm{CA} \mathrm{Ib}$ and $\mathrm{CA} \mathrm{Ia}, \lambda_{\max }$ was at $505 \mathrm{~nm}$ with a $\Delta E$ of $10.4 \times 10^{3}$ liters $\mathrm{mol}^{-1} \mathrm{~cm}^{-1}$.

The Neoprontosil difference spectrum of pigtail macaque CA II is similar to that for human CA II with regard to profile, molar absorbance, and wavelength of maximum molar absorbance difference (11). However, the pigtail macaque CA Ia and CA Ib difference spectra were not similar to the normal and variant forms of human CA I $(11,16)$. The macaque CA I isozymes lacked an absorption peak of positive sign at $550 \mathrm{~nm}$, and showed a molar absorbance and wavelength at peak absorbance difference of $10.4 \times 10^{3}$ liters $\mathrm{mol}^{-1} \mathrm{~cm}^{-1}$ and $505 \mathrm{~nm}$, respectively, which are significantly different from the human

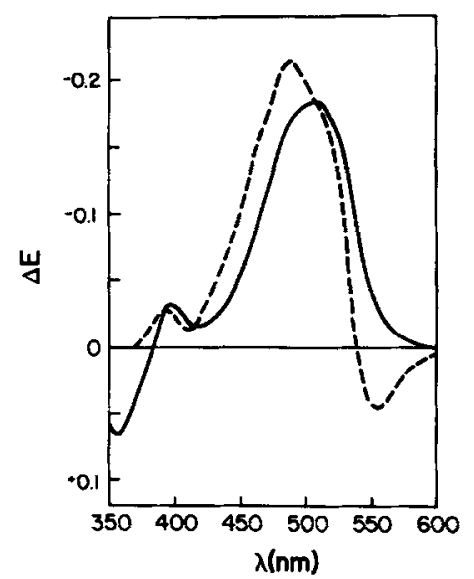

FIG. 1. Difference spectra at pH 7.5 of the Neoprontosil complexes of normal CA II (- - ) and the CA I variant, CA Ib (-), of the pigtail macaque. A zero-difference spectrum was obtained between reference and sample cuvettes containing neoprontosil in 0.1 м Hepes buffer, pH 7.5. The difference spectrum produced by inhibitor binding was obtained by adding a portion of enzyme to the sample cuvette and an equal volume of water to the reference cuvette so that the final enzyme concentration was $\sim 20 \mu \mathrm{M}$ and that of the inhibitor was $40 \mu \mathrm{M}$.

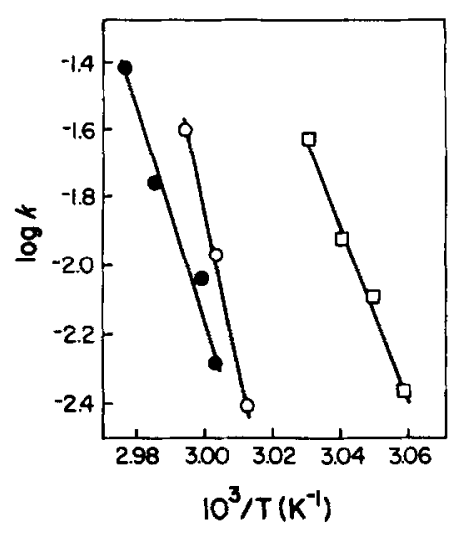

Fra. 2. Arrhenius plots of the rate constants $(k)$ for the heat degradation of normal CA II (O), and the CA I variants, CA Ia (D), and CA Ib (e) of the pigtail macaque. See Materials and Methods for experimental details.

CA I values of $488 \mathrm{~nm}$ and $7.6 \times 10^{3}$ liters $\mathrm{mol}^{-1} \mathrm{~cm}^{-1}$ previously reported (11).

\section{Heat Degradation}

To determine the first-order rate constants for heat degradation, the carbonic anhydrase isozymes were monitored from $0-50 \%$ inactivation. Because of differences in heat stabilities, the isozymes were tested over the temperature ranges $54-57^{\circ} \mathrm{C}$ for $\mathrm{CA} \mathrm{Ia}, 60-63^{\circ} \mathrm{C}$ for $\mathrm{CA} \mathrm{Ib}$, and $59-61^{\circ} \mathrm{C}$ for CA II. The results of duplicate experiments are shown in Fig. 2 in the form of Arrhenius plots of log (rate constant) against reciprocal of absolute temperature. The lines were calculated by linear regression analysis, and from the slopes the energies of activation $\left(E_{\mathrm{a}}\right)$ were obtained, which then gave the enthalpies of activation $(\Delta H \ddagger)$ at $55^{\circ} \mathrm{C}$. The equation to the line was used to calculate the rate constant at $55^{\circ} \mathrm{C}$ which, by using the theory of absolute reaction rates, gave the free energy of activation $(\Delta G \ddagger)$. From $\Delta H \ddagger$ and $\Delta E \ddagger$ the entropy of activation ( $\Delta S \ddagger$ ) was calculated.

These thermodynamic parameters are shown in Table I and a compensation plot of enthalpy versus entropy is shown in Fig. 3. For comparison, this figure includes previously reported data for human carbonic anhydrase isozymes (11) that have been 
TABLE I

Heat Degradation Values for CA I and CA II Isozymes of the Pigtail Macaque

\begin{tabular}{lccccc}
\hline Isozyme & $\begin{array}{c}10^{5} \times k \\
\left(\mathrm{~s}^{-1}\right)\end{array}$ & $\begin{array}{c}E_{a} \\
\left(\mathrm{~kJ} \mathrm{~mol}^{-1}\right)\end{array}$ & $\begin{array}{c}\Delta H \neq \\
\left(\mathrm{kJ} \mathrm{mol}^{-1}\right)\end{array}$ & $\begin{array}{c}\Delta G \ddagger \\
\left(\mathrm{kJ} \mathrm{mol}^{-1}\right)\end{array}$ & $\begin{array}{c}\Delta S \ddagger \\
\left(\mathrm{kJ} \mathrm{degree} \mathrm{mol}^{-1}\right)\end{array}$ \\
\hline CA Ib & 0.8 & 585.6 & 582.9 & 112.6 & 1.43 \\
CA Ia & 29.3 & 513.2 & 510.5 & 102.8 & 1.24 \\
CA II & 16.9 & 863.8 & 861.1 & 117.3 & 2.27 \\
\hline
\end{tabular}

corrected to account for an error of 2.303 in the $k$ values.

The heat degradation results showed a difference of about 40 -fold in $k$ values between CA Ia and CA Ib of the pigtail macaque. This large difference in CA Ia and $\mathrm{CA} \mathrm{Ib}$ is the result of the marked heat stability of CA Ib with a $k$ value of 0.8 $\times 10^{-5} \mathrm{~s}^{-1}$, in contrast to the $k$ value of 29.3 $\times 10^{-5} \mathrm{~s}^{-1}$ for CA Ia, which is in the range $11-28 \times 10^{-5} \mathrm{~s}^{-1}$ reported for human CA I and its variants $(11,12)$. The lower heat stability of the macaque CA Ia correlates with its deficiency in red cells relative to the $\mathrm{CA} \mathrm{Ib}(8,9)$. In a survey of four human red cell CA I isozymes, the largest difference in $k$ values was about 8 -fold, i.e., between the CA I variant, CA I Michigan-2, and the secondary isozyme of CA I, CA I $(+1)(11)$.

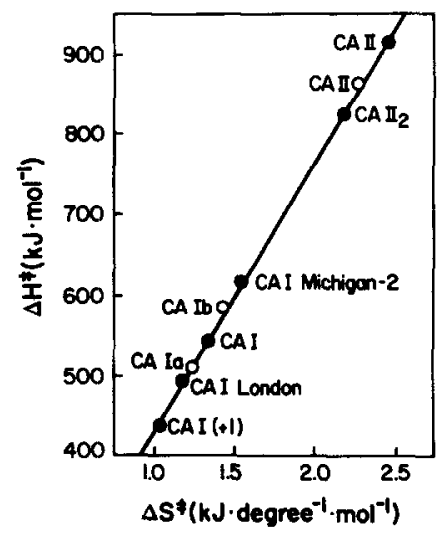

Fig. 3. Compensation plots of enthalpy $(\Delta H \ddagger)$ and entropy ( $\Delta S \ddagger)$ of activation for heat degradation at $55^{\circ} \mathrm{C}$ of normal and variant red cell carbonic anhydrase isozymes from humans ( $(\bullet)$ and pigtail macaques (O). Thermodynamic parameters were derived from Arrhenius plots (Fig. 2) as described under Results.
The compensation plot of enthalpy against entropy shows a segregation between the CA I and CA II isozymes. The pigtail macaque and human CA I isozymes are grouped together and have lower enthalpies and entropies of activation than the CA II isozymes, with about $200 \mathrm{~kJ} \mathrm{~mol}^{-1}$ separating these groups. The enthalpy-entropy plot also shows a highly correlated compensation between these thermodynamic parameters, reflecting the inherent structural molecular/genetic similarity of each class of isozymes. It will be of interest to see whether the enthalpy-entropy values of the CA I and CA II isozymes of other mammalian and nonmammalian species segregate in a similar manner. It will be especially interesting to determine similar parameters for the recently discovered CA III isozymes characteristic of red skeletal muscle (cf. Ref. (4)) and compare them with those of the CA I and CA II isozymes.

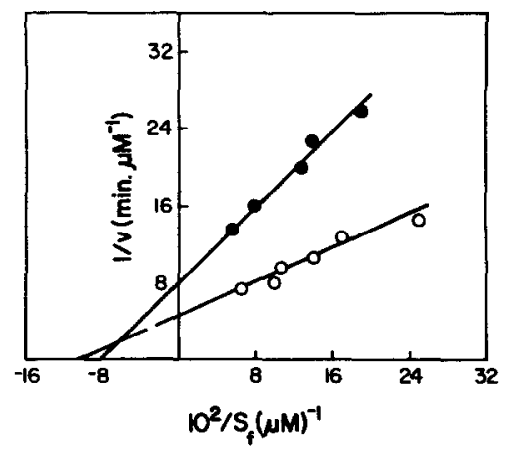

FIG. 4. Double-reciprocal plots of initial velocity and free substrate of the degradation by $\alpha$-chymotrypsin of the CA I variants, CA Ia (O) and CA Ib (๑) of the pigtail macaque. Reactions were at $45^{\circ} \mathrm{C}$ with $83 \mu \mathrm{M} \mathrm{CaCl}, 83 \mathrm{mM}$ Tris-HCl, pH 8.0, and 17.7 $\mu \mathrm{M} \alpha$-chymotrypsin. 
TABLE II

Proteolytic Degradation Values for CA I and CA II Isozymes of the Pigtatl Macaque

\begin{tabular}{ccccc}
\hline & $\begin{array}{c}\text { Erythrocyte } \\
\text { concentration } \\
(\mu \mathrm{g} / \mathrm{mg} \mathrm{Hb})\end{array}$ & $\begin{array}{c}K_{m} \\
(\mu \mathrm{M})\end{array}$ & $\begin{array}{c}10^{4} \times k_{\text {cat }} \\
\left(\mathrm{s}^{-1}\right)\end{array}$ & $\begin{array}{c}10^{6} \times k_{\text {cat }} / K_{m} \\
\left(\mu \mathrm{M}^{-1} \mathrm{~s}^{-1}\right)\end{array}$ \\
\hline CA Ib & 8.1 & 12.9 & 0.5 & 3.9 \\
CA Ia & 2.7 & 9.2 & 0.9 & 9.8 \\
CA II & 2.4 & 297.9 & 21.2 & 7.1 \\
\hline
\end{tabular}

a Estimated levels in CA Ia/CA Ib heterozygotes; from DeSimone et al. (8).

\section{Proteolytic Degradation}

Double-reciprocal plots from initial velocity and free substrate measurements using the CA I isozyme are shown in Fig. 4. The kinetic constants derived from these plots and a similar one for CA II are listed in Table II. The $k_{\text {cat }}$ values were calculated from the equation $V_{\max }=k_{\text {cat }} \mathrm{E}$, where $\mathrm{E}$ is the total concentration of $\alpha$-chymotrypsin.

The ratio of $k_{\text {cat }} / K_{m}$ was proposed by Brot and Bender (17) as an indicator of substrate specificity for $\alpha$-chymotrypsin. Using this ratio, the CA I and CA II isozymes of the pigtail macaque show similar specificities toward $\alpha$-chymotrypsin. This does not correlate with the data from human carbonic anhydrases where the CA I isozymes were more specific substrates for $\alpha$-chymotrypsin than the CA II isozymes, with mean $k_{\text {cat }} / K_{m}$ ratios of $23.5 \times 10^{-6}$ versus $9.2 \times 10^{-6} \mathrm{~s}^{-1}$ for human CA I and CA II, respectively (12).

The proteolytic data for pigtail macaque CA II are similar to those found for human CA II, where for the latter, the $k_{\text {eat }}=16.6$ $\times 10^{-4} \mathrm{~s}^{-1}$ and $k_{\text {cat }} / K_{m}=8.8 \times 10^{-6} \mathrm{~s}^{-1}(12)$, which complements the similarity in heat degradation constants between the macaque and human enzymes. The pigtail macaque $\mathrm{CA} \mathrm{Ia}$ is more susceptible to proteolysis than $\mathrm{CA} \mathrm{Ib}$, and this correlates with the heat degradation data and the relative deficiency of $\mathrm{CA} \mathrm{Ia}$ in their red cells $(8,9)$.

Thus, the finding that pigtail macaque red blood cells show approximately a $3 / 1$ ratio of $\mathrm{CA} \mathrm{Ib/CA} \mathrm{Ia,} \mathrm{although} \mathrm{both} \mathrm{iso-}$ zymes appear to be synthesized at a similar rate (8), could be accounted for by differential in vivo turnover which relates to their differences in heat and proteolytic degradation.

\section{ACKNOWLEDGMENTS}

We thank Ya-Shiou L. Yu for purifying the enzyme samples, and Dr. David Hewett-Emmett for his helpful suggestions with the manuscript.

\section{REFERENCES}

1. Spritz, R. A., AND Forget, B. G. (1983) Amer. J. Human Genet. 35, 335-361.

2. Melloni, E., Salamino, F., Sparatore, B., MichETT, M., AND PonTremolr, S. (1982) Arch. Biochem. Biophys. 216, 495-502.

3. Beutler, E. (1983) Proa Nath Acad. Sci. USA 80, 3767-3768.

4. Tashian, R. E., HewetT-Emmett, D., and GoodMAN, M. (1982) in Isozymes: Current Topies in Biological and Medical Research (Rattazzi, M. C., Scandalios, J. G., and Whitt, G. S., eds.) Vol. 7, pp. 79-100, Liss, New York.

5. KENDALl, A. G., AND TASHIAN, R. E. (1977) Science 197, 471-472.

6. Sly, W. S., HewetT-EmmetT, D., Whyte, M. P., Yu, Y.-S. L., and Tashian, R. E. (1983) Proc. Natl. Acad. Sci USA 80, 2752-2756.

7. Tashian, R. E., Goodman, M., Headings, V. E., DESIMONE, J., AND WARD, R. H. (1971) Biochem. Genet. 5, 183-200.

8. Desimone, J., MAGID, E., Linde, M., AND TAShian, R. E. (1973) Arch. Biochem. Biophys. 158, 365376.

9. Desimone, J., Magid, E., AND Tashian, R. E. (1973) Biochem. Genet. 8, 165-174.

10. Osborne, W. R. A., AND Tashian, R. E. (1975) Anal Biochem. 64, 297-303.

11. Osborne, W. R. A., ANd Tashian, R. E. (1974) Biochem. J. 141, 219-225.

12. Osborne, W. R. A., AND TASHIAN, R. E. (1981) J. Biol. Chem. 256, 1330-1334.

13. Sols, A., AND MARCo, R. (1970) Curr. Top. Cell Regul. 2, 227-273.

14. WILkINSON, G. N. (1961) Biochem. J. 80, 324-332.

15. Goldstein, A. (1944) J. Gen. Physiol 27, 529-580.

16. Kageoka, T., HewetT-Emmett, D., Stroup, S. K., YU, Y.-S. L., AND TASHIAN, R. E. (1981) Biochem. Genet. 19, 535-549.

17. Brot, E. F., AND Bender, M. L. (1969) J. Amer. Chem. Soc. 91, 7187-7191. 